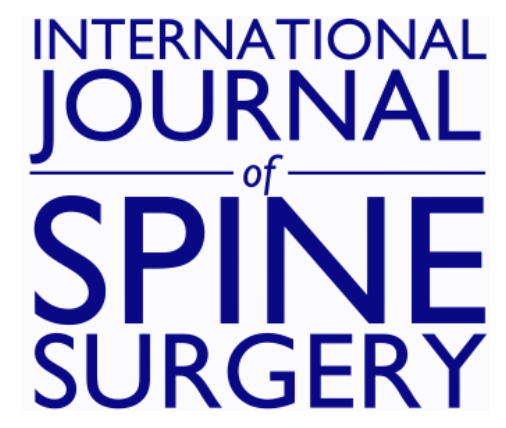

\title{
Cervical Disc Arthroplasty with Prestige LP Disc Versus Anterior Cervical Discectomy and Fusion: Seven-Year Outcomes
}

Matthew F. Gornet, J. Kenneth Burkus, Mark E. Shaffrey, Hui Nian and Frank E. Harrell, Jr

Int J Spine Surg 2016, 10 ()

doi: https://doi.org/10.14444/3024

http://ijssurgery.com/content/10/24

This information is current as of April 25, 2023.

Email Alerts Receive free email-alerts when new articles cite this article. Sign up at:

http://ijssurgery.com/alerts

The International Journal of Sdoing Surgehth 2397 Waterbury Circle, Suite 1,

Aurora, IL 60504, Phone: +1-630-375-1432

(C) 2016 ISASS. All Rights Reserved. 


\section{Cervical Disc Arthroplasty with Prestige LP Disc Versus Anterior Cervical Discectomy and Fusion: Seven-Year Outcomes}

Matthew F. Gornet, MD, ${ }^{1}$ J. Kenneth Burkus, MD, ${ }^{2}$ Mark E. Shaffrey, MD, ${ }^{3}$ Hui Nian, PhD, ${ }^{4}$ Frank E. Harrell, Jr. PhD 4

${ }^{1}$ The Orthopedic Center of St. Louis, St. Louis, Missouri, ${ }^{2}$ Wilderness Spine Services, The Hughston Clinic, Columbus, Georgia, ${ }^{3}$ Department of Neurosurgery, University of Virginia, Charlottesville, Virginia, ${ }^{4}$ Vanderbilt University School of Medicine, Department of Biostatistics, Nashville, Tennessee

\section{Abstract}

\section{Background}

Cervical disc arthroplasty (CDA) has emerged as an alternative to anterior cervical discectomy and fusion (ACDF) for the treatment of cervical pathologies. Studies are on-going to assess the long term outcomes of CDA. This study assessed the safety and efficacy of the Prestige ${ }^{\circledast}$ LP Disc at 84-months follow up.

\section{Methods}

Prospective data from 280 CDA patients with single-level cervical disc disease with radiculopathy or myelopathy were compared with 265 historical control ACDF patients. Clinical and radiographic follow up was completed preoperatively, intraoperatively, and at intervals up to 84 months.

\section{Results}

Follow-up rate was 75.9\% for CDA and 70.0\% for ACDF patients. Statistical improvements $(\mathrm{p}<0.001)$ in Neck Disability Index (NDI), neck/arm pain, and SF-36 were achieved by 1.5 months in both groups and maintained through 84 months. At 84 months, $86.1 \%$ of CDA versus $80.1 \%$ of ACDF patients achieved NDI success, ( $\geq 15$-point improvement over baseline). Mean NDI score improvements exceeded 30 points in both groups. SF-36 PCS/MCS mean improvements were $13.1 \pm 11.9 / 8.2 \pm 12.3$ points for CDA and 10.7 $\pm 11.8 / 8.3 \pm 13.6$ points for ACDF. Neurological success was $92.8 \%$ for CDA and $79.7 \%$ for ACDF patients. The rate of Overall Success was $74.9 \%$ for CDA and $63.2 \%$ for ACDF. At 84 months, $17.5 \%$ of CDA and 16.6\% of ACDF patients had a possibly implant- or implant-surgical procedure-related adverse event. Eighteen (6.4\%) CDA and 29 (10.9\%) ACDF patients had a second surgery at the index level. In CDA patients, mean angular motion at the target level was maintained at 24 $\left(7.5^{\circ}\right)$ and $84\left(6.9^{\circ}\right)$ months. Bridging bone was reported in 5.9\%/9.5\%/10.2\%/13.0\% of CDA patients at 24/36/60/ 84 months. Change in mean preoperative angulation of the adjacent segment above/below the index level was1.06 $\pm 4.39 / 1.25 \pm 4.06$ for CDA and (-0.23) $\pm 5.37 / 1.25 \pm 5.07$ for ACDF patients. At 84 months, $90.9 \%$ of CDA and $85.6 \%$ of ACDF patients were satisfied with the results of their treatment.

\section{Conclusions}

Prestige LP maintained significantly improved clinical outcomes and segmental motion; statistical superiority of CDA was concluded for overall success.

This investigational device exemption study was sponsored by Medtronic Spinal and Biologics, Memphis, TN. Study approved by the Hughston Sports Medicine Center Institutional Review Board on January 7, 2005. Clinical trial registered at clinicaltrials.gov: NCT00667459. All participants signed an informed consent.

KEYWORDS: CERVICAL DISC ARTHROPLASTY, ANTERIOR CERVICAL DISCECTOMY AND FUSION, ARTIFICIAL CERVICAL DISC, CERVICAL RADICULOPATHY, CERVICAL MYELOPATHY, ADJACENT LEVEL DISEASE

VOLUME 10 ARTICLE 24 DOI: 10.14444/3024

\section{Introduction}

Seven cervical disc arthroplasty (CDA) devices have now been approved by the U.S. Food and Drug Administration (FDA) for the treatment of symptomatic cervical degenerative disc disease (DDD). Twenty- 
four-month Investigational Device Exemption (IDE) studies have revealed CDA outcomes to be at least comparable to anterior cervical discectomy and fusion (ACDF). ${ }^{1-6}$ More recently, longer-term evidence has been published for many of these same devices, demonstrating the continued safety and efficacy of CDA for appropriately selected patients. ${ }^{7-11}$

Decompression of the neural elements and permanent stabilization of the cervical spine through $\mathrm{ACDF}$ is an effective treatment for surgical candidates suffering intractable neck pain and/or increasing neurological deficit. Cervical disc arthroplasty has the potential to maintain anatomic disc space height, normal segmental lordosis, and physiologic motion patterns after surgery. Widely reported complications, which gave rise to the initial interest in cervical artificial disc replacement as an alternative to fusion, continue to be a concern worthy of exploration in these and other long-term studies. ${ }^{12-21}$

This study was undertaken to investigate the longterm safety and efficacy of the Prestige ${ }^{\circledR}$ LP Disc (Medtronic Spinal and Biologics, Memphis, TN). The FDA-approved Prestige LP disc is an unconstrained ball-in-trough, metal-on-metal articulation composed of a titanium ceramic composite (Figure 1). The early 24-month clinical and radiographic outcomes for this device have been reported previous$\mathrm{ly}^{22}$ We report the 7-year data from the FDA IDE study in patients undergoing single-level anterior cervical discectomy and disc arthroplasty with the cervical disc implant and compare them with those in patients undergoing single-level ACDF.

\section{Methods}

\section{Study Design}

This prospective multicenter study was conducted under an approved FDA IDE. Patients in the original 24-month study (clinicaltrials.gov: NCT00667459) were consented after institutional review board approval and followed in this FDA-regulated study for an additional 5 years.

From January to November 2005, 280 nonrandomized patients were enrolled at 20 investigational sites and received treatment for single-level cervical de- generative disc disease using a low-profile cervical disc arthroplasty device. The safety and efficacy outcomes for these patients were compared with data from the 265 historical control patients from a previous FDA-approved IDE study (IDE \#G010188; clinicaltrials.gov: NCT00642876) with identical inclusion-exclusion criteria who underwent anterior cervical discectomy and fusion with allograft bone and an anterior plate, utilizing a similar surgical approach. Patients in the study were evaluated preoperatively, intraoperatively, and at routine postoperative intervals of 1.5, 3, 6, 12, 24, 36, 60 and 84 months. Adverse events and secondary surgical procedures were recorded at each follow-up interval.

\section{Independent Data Review}

As with the publication of the 24-month results, ${ }^{22}$ the study sponsor delivered the entire database of raw data to independent biostatisticians at Vanderbilt University for analysis. Using the FDA-approved methods from the original statistical plan, analysis by the independent team that is presented in this report reached the same statistical conclusions as the study sponsor's analysis. Statisticians for the sponsor used the statistical software SAS (SAS Institute, Cary NC) to generate the summary tables and WinBUGS to conduct the Bayesian analysis. Independent statisticians at Vanderbilt used R software for the summary tables and JAGS to conduct the Bayesian analysis.

\section{Statistical Analysis}

Bayesian statistical methods are increasingly evident in the peer-reviewed literature for spinal device tri-

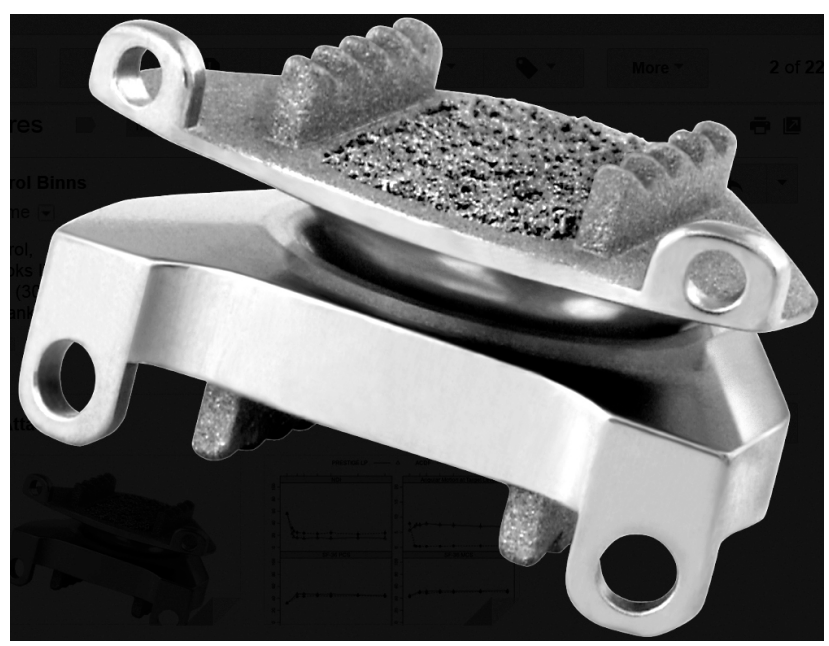

Fig. 1. The Prestige LP Cervical Disc. 
als. ${ }^{1,6}$ Bayesian results are "positive" when, for example, the posterior probability of efficacy $\geq 0.95$ (in the more commonly used and more familiar Frequentist approach, evidence for efficacy is generally thought to be provided by $\mathrm{p} \leq 0.05$ ). For assessing study data, the Bayesian posterior probability of a statement ("Treatment A tends to be better than Treatment B") is the probability that the statement is true. Furthermore, 95\% Bayesian Credible Intervals (BCI) are provided for study parameters of interest. A detailed discussion of the statistical analysis plan is presented in the publication of 24-month outcomes. ${ }^{22}$ In addition, time-to-event analysis was performed for adverse events and secondary surgery events using a Cox proportional hazards model with adjustment for propensity score.

\section{Clinical Outcome Measures}

Patient-reported clinical outcomes were measured using validated instruments including Neck Disability Index (NDI) and the 36-Item Medical Outcomes Study Short-Form Health Survey ${ }^{23}$ (SF-36); Neck pain and arm pain numeric rating scales (duration 0-10 multiplied by intensity $0-10$, adapted in part from McDowell et al.), ${ }^{24}$ neurological status, patient satisfaction, and work status were also assessed. Patient examinations were conducted preoperatively and immediately after surgery, and self-reported outcomes questionnaires were completed before surgery and at each postoperative follow-up interval.

The primary clinical outcome measure for this study was Overall Success, a composite measure consisting of all of the following conditions: 1) NDI Success, defined as NDI score improvement of at least 15 points; 2) Neurological Success, defined as maintenance or improvement in neurological status; 3 ) Functional Spinal Unit (FSU) Success, defined as maintenance or improvement in disc height and no evidence of subsidence; 4) no serious adverse event (AE) classified as implant or implant/surgical procedure associated; and 5) no secondary surgical procedure classified as a "failure" (Table 1).

FSU Success was an FDA-mandated component of Overall Success, but the measurement was frequently difficult or impossible to obtain due to visualization hindrances on radiographic images of both in- vestigational and control patients, in which case those patients were excluded from the Overall Success analysis. For this reason, Overall Success results are presented both with and without FSU Success as a component.

\section{Radiographic Assessment}

Plain radiographs were obtained preoperatively, intraoperatively, and at $1.5,3,6,12,24,36,60$, and 84 months to characterize the radiographic measurement of the investigational device and to assess fusion success in the control group. Two independent radiologists from the core lab were trained and performed radiographic assessment measurements utilizing an orthopaedic reading system and digitized images of plain radiographs. A third independent reviewer adjudicated conflicting findings.

Using vertebral endplate distances to measure disc height was expected to be difficult due to visualization challenges created by the CDA implant, despite being low profile. Formation of a solid fusion mass can also potentially obscure measurement landmarks after ACDF. For those reasons, FSU height was chosen as an alternative method for evaluating the maintenance of disc height or directly determining whether the implant had subsided. FSU Success was

\begin{tabular}{|c|c|}
\hline & \\
\hline Varrables & Definition \\
\hline $\begin{array}{l}\text { Neck Disability Index } \\
\text { (NDI) Success }\end{array}$ & $\begin{array}{l}\geq 15 \text {-point improvement postoperatively com- } \\
\text { pared to preoperative score }\end{array}$ \\
\hline $\begin{array}{l}\text { Neurological Status Suc- } \\
\text { cess }\end{array}$ & $\begin{array}{l}\text { Maintenance or improvement in postoperative } \\
\text { neurological status (motor function, sensory } \\
\text { function, and reflexes) compared to preoperative } \\
\text { condition }\end{array}$ \\
\hline $\begin{array}{l}\text { Functional Spinal Unit } \\
\text { (Disc Height) Success }\end{array}$ & $\begin{array}{l}\text { Functional spinal unit anterior or posterior mea- } \\
\text { surement height declined by no more than } 2 \mathrm{~mm} \\
\text { vs. the 6-week postoperative assessment }\end{array}$ \\
\hline $\begin{array}{l}\text { No serious adverse event } \\
\text { classified as implant or im- } \\
\text { plant/surgical procedure } \\
\text { associated }\end{array}$ & $\begin{array}{l}\text { Serious } \mathrm{AE}=\text { Grade } 3 \text { or Grade } 4 \text { per World } \\
\text { Health Organization criteria (typically, resulting } \\
\text { in ER visit or hospitalization) }\end{array}$ \\
\hline $\begin{array}{l}\text { No secondary surgical pro- } \\
\text { cedure classified as a "fail- } \\
\text { ure" }\end{array}$ & $\begin{array}{l}\text { Supplemental fixation, removal or revision }= \\
\text { treatment failure. Reoperation or other surgical } \\
\text { procedure } \neq \text { treatment failure }\end{array}$ \\
\hline
\end{tabular}


concluded when neither the anterior nor posterior measurement had declined by more than $2 \mathrm{~mm}$ compared with the 1.5-month postoperative assessment.

Segmental motion at the index and superior/inferior adjacent levels was measured on lateral dynamic flexion-extension radiographs using the Cobb method. Radiographic Success required angular motion at the level of surgery to be $>4^{\circ}$ but $<20^{\circ}$ at each postoperative interval.

\section{Device Safety/Adverse Events}

In addition to Neurological Success - maintenance or improvement in motor function, sensory function, and reflexes - the nature and frequency of adverse events were compared between study groups. An AE mapping scheme for terms and categories of AEs was proposed by the FDA, based in part on the study sponsor's internal AE process and in part on the MedDRA (Medical Dictionary for Regulatory Activities) coding system. This hybrid places each of 20 classifications of AEs under a broad body system (e.g., neurological, cardiac disorders), incident (e.g., trauma, infection), or other (associated conditions/ systems with small numerical incidence). Adverse events were analyzed and characterized by their na- ture into categories, and graded according to World Health Organization criteria as "nonserious" (Grade 1 or 2) or "serious" (Grade 3 or 4) events. Reported AEs were likewise classified based on their potential relation to the implant and/or the surgical procedure. The AE data submitted to FDA, and used for this publication, were generated by a committee of three independent physicians which adjudicated all $\mathrm{AE}$ relationships and their severity. An adverse event that resulted in a second surgical procedure would cause the patient to be classified as a study "failure" with respect to the Overall Success determination if it required a supplemental fixation, implant removal, or a revision.

\section{Patient Demographics}

Patients in the nonrandomized investigational group and the historical control group were similar demographically (Table 2). Propensity scores were calculated using logistic regression modeling and included in the outcome models to adjust for possible effects of demographic characteristics or preoperative measures on clinical outcomes. Covariate balance after propensity score adjustment was examined using ANCOVA or logistic regression. 
Table 2. Patient demographic and preoperative characteristics: median, interquartile range, (mean \pm standard deviation) or percent (count) (Reprinted with permission from Gornet MF, Burkus JK, Shaffrey ME, Argires PJ, Nian $\mathrm{H}$, Harrell FE: Cervical disc arthroplasty with PRESTIGE LP disc versus anterior cervical discectomy and fusion: a prospective, multicenter investigational device exemption study. J Neurosurg Spine. 2015 Jul 31:1-16. [Epub ahead of print] PMID: 26230424.22)

\begin{tabular}{|c|c|c|c|c|c|c|c|}
\hline & & Investigational & & Control & & P val & ter PS Adjustmen \\
\hline & & & & $(\mathrm{N}=265)$ & p Value before PS Adjustment ${ }^{*}$ & PS as Continuous Covariate $^{\dagger}$ & PS Stratification \\
\hline Age (yrs) & 394449 & $(44.5 \pm 8.8)$ & 384449 & $(43.9 \pm 8.8)$ & 0.369 & 0.997 & 0.873 \\
\hline Height (in) & 646771 & $(67.7 \pm 4.1)$ & 646771 & $(67.5 \pm 4.2)$ & 0.622 & 0.998 & 0.946 \\
\hline Weight (lbs) & 154180218 & $(186.9 \pm 45.0)$ & 155181210 & $(184.7 \pm 41.5)$ & 0.565 & 0.998 & 0.962 \\
\hline NDI score & 445466 & $(55.5 \pm 14.7)$ & 445868 & $(56.4 \pm 15.9)$ & 0.499 & 0.997 & 0.952 \\
\hline SF36 PCS score & 27.432 .436 .7 & $(32.2 \pm 7.4)$ & 27.131 .536 .6 & $(32.0 \pm 7.5)$ & 0.775 & 0.999 & 0.898 \\
\hline SF36 MCS score & 34.946 .553 .6 & $(44.5 \pm 11.5)$ & 33.142 .153 .0 & $(42.7 \pm 12.4)$ & 0.078 & 0.993 & 0.924 \\
\hline Neck pain score & 507081 & $(60.7 \pm 20.8)$ & 567281 & $(69.3 \pm 21.5)$ & 0.190 & 0.995 & 0.987 \\
\hline Arm pain score & 406480 & $(59.6 \pm 26.3)$ & 426783 & $(62.4 \pm 28.5)$ & 0.237 & 0.995 & 0.960 \\
\hline Female & $53.9 \%$ & $(151)$ & $54.0 \%$ & (143) & 1.000 & 1.000 & 0.881 \\
\hline Race & & & & & 0.075 & 0.997 & 0.708 \\
\hline Caucasian & $96.8 \%$ & (271) & $91.7 \%$ & (243) & & & \\
\hline Black & $2.5 \%$ & (7) & $4.9 \%$ & (13) & & & \\
\hline Asian & $0.0 \%$ & (0) & $0.8 \%$ & (2) & & & \\
\hline Hispanic & $0.4 \%$ & (1) & $2.3 \%$ & (6) & & & \\
\hline Other & $0.4 \%$ & (1) & $0.4 \%$ & (1) & & & \\
\hline Marital status & & & & & 0.109 & 0.990 & 0.749 \\
\hline Single & $14.3 \%$ & (40) & $12.1 \%$ & (32) & & & \\
\hline Married & $67.5 \%$ & (189) & $77.0 \%$ & (204) & & & \\
\hline Divorced & $15.0 \%$ & (42) & $9.1 \%$ & (24) & & & \\
\hline Separated & $2.5 \%$ & (7) & $1.1 \%$ & (3) & & & \\
\hline Widowed & $0.7 \%$ & (2) & $0.8 \%$ & (2) & & & \\
\hline Education level & & & & & 0.063 & 0.991 & 0.877 \\
\hline$<$ High school & $5.4 \%$ & (15) & $5.3 \%$ & (14) & & & \\
\hline High school & $20.5 \%$ & (57) & $29.2 \%$ & (77) & & & \\
\hline$>$ High school & $74.1 \%$ & (206) & $65.5 \%$ & (173) & & & \\
\hline Workers' compensation case & $11.4 \%$ & (32) & $13.2 \%$ & (35) & 0.616 & 0.998 & 0.864 \\
\hline Unresolved spinal litigation case & $12.1 \%$ & (34) & $12.1 \%$ & (32) & 1.000 & 1.000 & 0.928 \\
\hline Tobacco used & $26.4 \%$ & (74) & $34.7 \%$ & (92) & 0.045 & 0.991 & 0.893 \\
\hline Alcohol used & $53.6 \%$ & $(150)$ & $53.2 \%$ & (141) & 1.000 & 1.000 & 0.900 \\
\hline Working before operation & $67.1 \%$ & (188) & $62.6 \%$ & (166) & 0.312 & 0.996 & 0.968 \\
\hline Non-narcotic relaxant medication use & $74.3 \%$ & (208) & $71.1 \%$ & (187) & 0.462 & 0.997 & 0.836 \\
\hline Weak narcotic medication use & $47.7 \%$ & (133) & $48.3 \%$ & (127) & 0.954 & 1.000 & 0.843 \\
\hline Strong narcotic medication use & $22.2 \%$ & $(62)$ & $22.0 \%$ & $(58)$ & 1.000 & 1.000 & 0.995 \\
\hline Muscle relaxant medication use & $35.8 \%$ & $(100)$ & $43.2 \%$ & (114) & 0.097 & 0.993 & 0.977 \\
\hline Time to start having symptoms & & & & & 0.488 & 0.999 & 0.992 \\
\hline$<6$ weeks & $7.9 \%$ & (22) & $5.7 \%$ & (15) & & & \\
\hline 6 weeks to 6 months & $30.4 \%$ & (85) & $33.6 \%$ & (89) & & & \\
\hline$>6$ months & $61.8 \%$ & (173) & $60.8 \%$ & (161) & & & \\
\hline Normal motor functions & Downloaded 9 frơn & http://ijssurlger & om/ by guest 69 & pril 25,26823 & $<0.001$ & 0.979 & 0.751 \\
\hline
\end{tabular}




\begin{tabular}{|c|c|c|c|c|c|c|c|}
\hline Normal sensory functions & $41.8 \%$ & (117) & $50.9 \%$ & (135) & 0.040 & 0.991 & 0.890 \\
\hline Normal reflexes & $66.4 \%$ & (186) & $61.1 \%$ & (162) & 0.231 & 0.995 & 0.888 \\
\hline Normal gait score & $93.6 \%$ & $(262)$ & $77.0 \%$ & (204) & $<0.001$ & 0.881 & 0.467 \\
\hline Positive foraminal compression test & $42.9 \%$ & $(120)$ & $54.3 \%$ & (144) & 0.009 & 0.989 & 0.875 \\
\hline Treatment level & & & & & 0.201 & 0.989 & 0.981 \\
\hline C3-C4 & $1.4 \%$ & (4) & $3.8 \%$ & (10) & & & \\
\hline C4-C5 & $7.5 \%$ & (21) & $5.7 \%$ & (15) & & & \\
\hline $\mathrm{C} 5-\mathrm{C} 6$ & $52.5 \%$ & (147) & $56.2 \%$ & (149) & & & \\
\hline C6-C7 & $38.6 \%$ & $(108)$ & $34.3 \%$ & (91) & & & \\
\hline
\end{tabular}

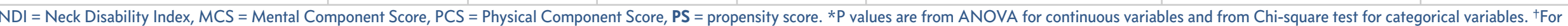

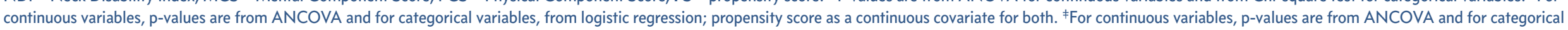

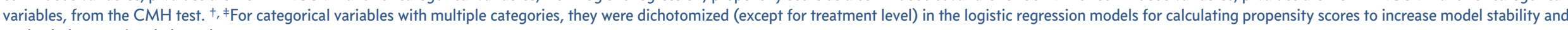
to check the covariate balance between treatment groups. 
Eligible patients, who consented and were enrolled at sites with institutional review board approval, were all considered candidates for single-level ACDF because of symptomatic cervical DDD at a single level from C3-4 to C6-7, including neck and arm pain that was recalcitrant to nonoperative measures. These nonoperative treatment modalities may have included reduction of painful activities, physical therapy, anti-inflammatory medications, and other directed programs, for at least 6 weeks before surgery (Table 3).

\section{Results}

\section{Patient Accountability}

In the investigational CDA group, 280 patients were enrolled and treated at 20 separate sites. The historical control group consisted of 265 patients treated with ACDF. Follow-up rates at 84 months were
$75.9 \%$ for the investigational group and $70.0 \%$ for the control group, based on the availability of Overall Success (without FSU) outcomes. Follow-up rates based on the availability of any data on a patient at a given study period were $82.0 \%$ for CDA patients and 76.2\% for ACDF patients.

\section{Patient Demographics}

Despite the use of an historical control, the investigational and control groups were similar demographically because inclusion and exclusion criteria were the same for both FDA studies. Statistical differences in tobacco use (higher in the control group) and in race were appropriately balanced for statistical comparison after the application of propensity score adjustment techniques. There were no statistical differences between groups with respect to preoperative medical history or condition, medical usage, or preoperative scores of key efficacy endpoints. Overall,

Table 3. Study patient inclusion and exclusion criteria. Reprinted with permission from Gornet MF, Burkus JK, Shaffrey ME, Argires PJ, Nian H, Harrell FE: Cervical disc arthroplasty with PRESTIGE LP disc versus anterior cervical discectomy and fusion: a prospective, multicenter investigational device exemption study. J Neurosurg Spine. 2015 Jul 31:1-16. [Epub ahead of print] PMID: 26230424.22

\begin{tabular}{|c|c|}
\hline INCLUSION (ALL) & EXCLUSION (ANY) \\
\hline $\begin{array}{l}\text { Cervical degenerative disc disease de- } \\
\text { fined as intractable radiculopathy and/ } \\
\text { or myelopathy with at least one of the } \\
\text { following items producing symptomatic } \\
\text { nerve root and/or spinal cord compres- } \\
\text { sion that is documented by patient his- } \\
\text { tory [(e.g., pain, functional deficit, and/ } \\
\text { or neurological deficit radiographic } \\
\text { studies (e.g., CT, MRI, x-rays, etc.)]: } \\
\text { - herniated disc } \\
\text { - osteophyte formation } \\
\text { - One level requiring surgical treatment } \\
\text { - C3-C4 disc to C6-C7 disc level of in- } \\
\text { volvement } \\
\text { - Unresponsive to nonoperative treatment } \\
\text { for approximately six weeks or has the } \\
\text { presence of progressive symptoms or } \\
\text { signs of nerve root/spinal cord compres- } \\
\text { sion in the face of continued nonopera- } \\
\text { tive management } \\
\text { No previous surgical intervention at the } \\
\text { involved level or any subsequent, } \\
\text { planned/staged surgical procedure at } \\
\text { the involved or adjacent level(s) } \\
\text { Is at least } 18 \text { years of age, inclusive, at } \\
\text { the time of surgery } \\
\text { Preoperative Neck Disability Index } \\
\text { score } \geq 30 \\
\text { Has a preoperative neck pain score of } \\
\geq 20 \text { based on the Preoperative Neck and } \\
\text { Arm Pain Questionnaire } \\
\text { If a female of child-bearing potential, } \\
\text { patient is not pregnant, at the time of } \\
\text { surgery } \\
\text { Is willing to comply with the study plan } \\
\text { and sign the Patient Informed Consent } \\
\text { Form }\end{array}$ & $\begin{array}{l}\text { - Has a cervical spinal condition other than symptomatic cervical disc disease requiring surgical treatment at the } \\
\text { involved level; } \\
\text { - } \text { Documented or diagnosed cervical instability defined by dynamic (flexion/extension) radiographs showing: } \\
\text { - Sagittal plane translation }>3.5 \mathrm{~mm} \text { or } \\
\text { - } \text { Mogittal plane angulation }>20^{\circ} \\
\text { - Has a fused level adjacent to the level to be treated } \\
\text { - Has severe pathology of the facet joints of the involved vertebral bodies } \\
\text { - Previous surgical intervention at the involved level } \\
\text { - Has been previously diagnosed with osteopenia or osteomalacia } \\
\text { - Has any of the following that may be associated with a diagnosis of osteoporosis (if "Yes" to any of the below } \\
\text { risk factors, a bone density scan will be required to determine eligibility): } \\
\text { - Postmenopausal non-Black female over } 60 \text { years of age and weighs less than } 140 \text { pounds } \\
\text { - Male over the age of } 70 \\
\text { - Male over the age of } 60 \text { that has sustained a non-traumatic hip or spine fracture } \\
\text { - If the level of BMD is a T score of }-3.5 \text { or lower (i.e., }-3.6,-3.7, \text { etc.) or a T score of }-2.5 \text { or lower (i.e., }-2.6, \\
\text { - } 2.7, \text { etc.) with vertebral crush fracture, then the patient is excluded from the study } \\
\text { - Has presence of spinal metastases } \\
\text { - Has overt or active bacterial infection, either local or systemic } \\
\text { - Has chronic or acute renal failure or prior history of renal disease } \\
\text { - Has fever (temperature }>101^{\circ} F \text { oral) at the time of surgery } \\
\text { - Has a documented allergy to stainless steel, titanium, or a titanium alloy } \\
\text { - Is mentally incompetent (If questionable, obtain psychiatric consult) } \\
\text { - Is a prisoner } \\
\text { - Is pregnant } \\
\text { - Is an alcohol and/or drug abuser as defined by currently undergoing treatment for alcohol and/or drug abuse } \\
\text { - Has received drugs which may interfere with bone metabolism within two weeks prior to the planned date of } \\
\text { spinal surgery (e.g., steroids or methotrexate), excluding routine perioperative anti-inflammatory drugs } \\
\text { tive anti-inflammatory drugs } \\
\text { Has received treatment with an investigational therapy within } 28 \text { days prior to implantation surgery or such treat- } \\
\text { ment is planned during the } 16 \text { weeks following Artificial Cervical Disc-LP implantation }\end{array}$ \\
\hline
\end{tabular}


the 2 study groups were similar prior to surgery (Table 2), with potential confounding effects statistically adjusted, such that conclusions reached by the statisticians were based on treatment effect rather than any potential confounding influences.

\section{Surgical Data}

More than $90 \%$ of patients in each group were treated at the C5-C6 or C6-C7 level using a standard extrapharyngeal anterolateral approach. Mean operative time in the investigational and control groups was 1.49 hours and 1.38 hours, respectively, a statistically significant difference of approximately $6.5 \mathrm{~min}$ utes (95\% credible interval, 0.01 to 0.21 hours). Blood loss $(51.0 \mathrm{~mL}$ - investigational and $57.1 \mathrm{~mL}$ - control) and hospital stay (0.98 day - investigational and 0.95 day - control) were not statistically different between the groups.

\section{Overall Success}

At 84 months, the rate of Overall Success (without FSU height success) in the investigational group exceeded the rate in the control group by 0.109 (95\% credible interval 0.011 to 0.208 ), and with FSU by 0.001 ( $95 \%$ credible interval -0.122 to 0.125 ), respectively (Table 4). The posterior probability that the

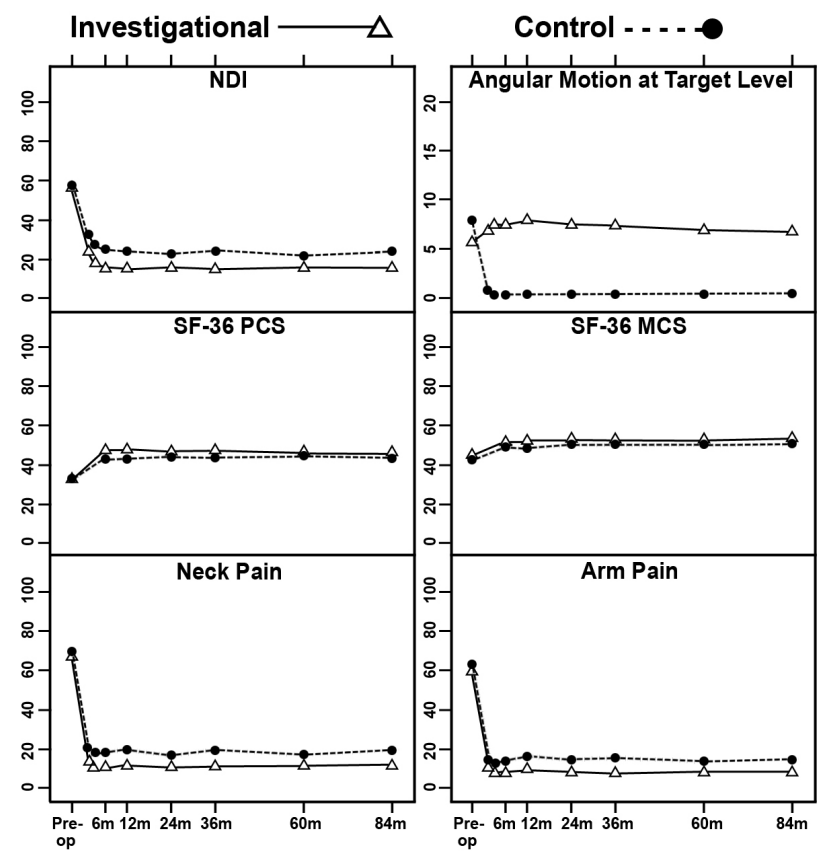

Fig. 2. Mean Neck Disability Index (NDI), angular motion at target level, Short-Form-36 Physical Component Summary (SF-36 PCS), Short-Form-36 Mental Component Summary (SF-36 MCS), and neck pain and arm pain scores of the 2 treatment groups at baseline and postoperative time points. Vertical bars indicate $99 \%$ confidence intervals of the means.
Overall Success rate (without FSU) in the investigational group was higher than the control group was 0.985 , indicating statistical superiority.

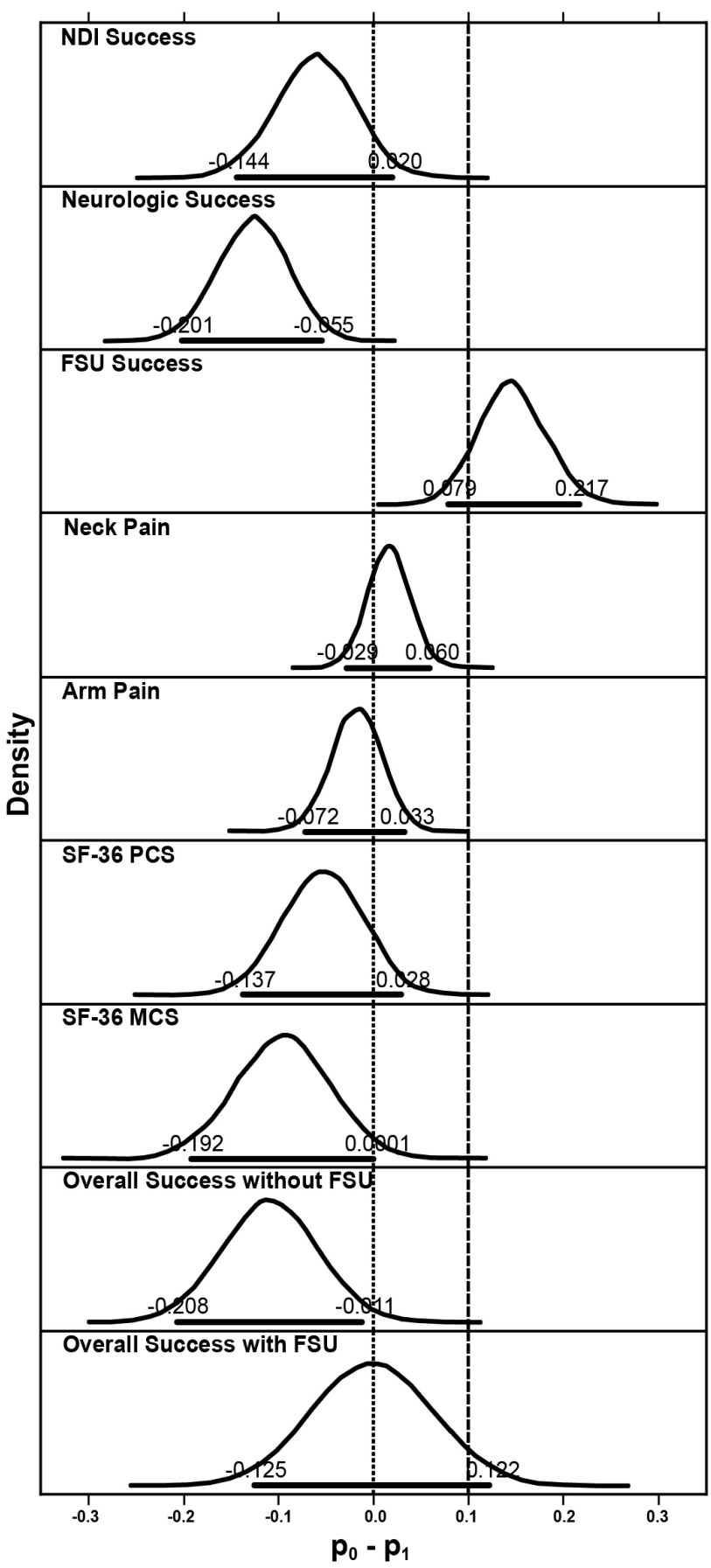

Fig. 3. Posterior distributions of differences in success rates of efficacy and neurological variables between the 2 treatment groups. Horizontal bold lines indicate 95\% HPD, upper and lower limits of which are also labeled. Dashed vertical line is upper limit of noninferiority and dotted vertical line is upper limit of superiority. FSU = functional spinal unit, HPD = highest posterior density, NDI = Neck Disability Index, SF-36 MCS =

Short-Form-36 Mental Component Summary, SF-36 PCS = Short-Form-36 Physical Component Summary. 
Table 4. Comparisons of efficacy and neurological variables at 84 months.

\begin{tabular}{|c|c|c|c|c|c|c|c|c|c|c|}
\hline \multirow[t]{2}{*}{ Measure } & \multirow[b]{2}{*}{$\%$ Investigational } & \multirow[b]{2}{*}{$\%$ Control } & \multicolumn{2}{|c|}{$\mathbf{p}_{1}$ (Investigational) } & \multicolumn{2}{|r|}{$p_{0}($ Control $)$} & \multicolumn{2}{|r|}{$\mathbf{p}_{0}-\mathbf{p}_{1}$} & \multicolumn{2}{|c|}{ Probability of Superiority } \\
\hline & & & Mean & $95 \% \mathrm{HPD}$ & Mean & $95 \%$ HPD & Mean & $95 \%$ HPD & Non-inferiority & Superiority \\
\hline NDI & $86.06 \%(179 / 208)$ & $80.11 \%(145 / 181)$ & 0.862 & $(0.810,0.908)$ & 0.801 & $(0.735,0.859)$ & -0.061 & $(-0.144,0.020)$ & $\sim 1.000$ & 0.932 \\
\hline Neurological status & $92.75 \%(192 / 207)$ & $79.67 \%(145 / 182)$ & 0.927 & $(0.887,0.959)$ & 0.800 & $(0.737,0.858)$ & -0.127 & $(-0.201,-0.055)$ & $\sim 1.000$ & $\sim 1.000$ \\
\hline FSU & $83.65 \%(133 / 159)$ & $96.85 \%(123 / 127)$ & 0.827 & $(0.761,0.885)$ & 0.973 & $(0.940,0.993)$ & 0.146 & $(0.079,0.217)$ & 0.093 & 0.000 \\
\hline Neck pain & $94.69 \%(196 / 207)$ & $95.56 \%(172 / 180)$ & 0.945 & $(0.908,0.972)$ & 0.961 & $(0.928,0.984)$ & 0.016 & $(-0.029,0.060)$ & $\sim 1.000$ & 0.234 \\
\hline Arm pain & $94.20 \%(195 / 207)$ & $92.78 \%(167 / 180)$ & 0.945 & $(0.908,0.972)$ & 0.927 & $(0.884,0.961)$ & -0.018 & $(-0.072,0.033)$ & $\sim 1.000$ & 0.748 \\
\hline SF-36 PCS & $85.29 \%(174 / 204)$ & $79.21 \%(141 / 178)$ & 0.851 & $(0.797,0.898)$ & 0.797 & $(0.732,0.856)$ & -0.053 & $(-0.137,0.028)$ & $\sim 1.000$ & 0.894 \\
\hline SF-36 MCS & $77.45 \%(158 / 204)$ & $70.22 \%(125 / 178)$ & 0.786 & $(0.724,0.840)$ & 0.690 & $(0.616,0.758)$ & -0.095 & $(-0.192,0.0001)$ & $\sim 1.000$ & 0.975 \\
\hline Overall success (w/o FSU) & $74.88 \%(158 / 211)$ & $63.19 \%(115 / 182)$ & 0.746 & $(0.683,0.804)$ & 0.637 & $(0.563,0.709)$ & -0.109 & $(-0.208,-0.011)$ & $\sim 1.000$ & 0.985 \\
\hline Overall success (w/FSU) & $62.05 \%(103 / 166)$ & $60.00 \%(81 / 135)$ & 0.612 & $(0.533,0.688)$ & 0.611 & $(0.520,0.696)$ & -0.001 & $(-0.125,0.122)$ & 0.947 & 0.508 \\
\hline
\end{tabular}

FSU = functional spinal unit, HPD = highest posterior density, MCS = Short Form-36 Mental Component Summary, NDI = Neck Disability Index, SF-36 PCS = Short Form-36 Physical Component Summary. 
Efficacy Endpoints

For both the investigational and control groups, improvements in pain and disability scores compared with preoperative assessments were highly significant ( $\mathrm{p}<0.001$, paired $t$-tests) for NDI, SF-36 PCS and MCS, numeric neck pain and arm pain scores, from 1.5 months after surgery up to 84 months (Figure 2). Mean NDI improvement in both groups exceeded 30 points from 6 months after surgery through 84 months.

Bayesian methods were used to evaluate the secondary endpoints. Compared with the control fusion group, the investigational group achieved higher numerical rates of NDI success, neurological success, arm pain success, SF-36 PCS success and MCS success at 84 months; success rates were numerically lower than the control group for FSU height and neck pain (Table 4). The posterior probabilities that the success rate in the control group was less than $10 \%$ higher than in the investigational group were essentially 1.0 for all outcomes except FSU height, thus demonstrating statistical noninferiority of the investigational group to the control group for these outcomes 7 years after surgery (Figure 3 ). The posterior probabilities that the success rate in the investigational group was higher than control group were essentially $1.000,0.975$, and 0.985 for neurological status, SF-36 MCS, and Overall Success without FSU. These Bayesian probabilities exceeded the threshold of 0.95 , providing for a conclusion of statistical superiority of the investigational group over the control group for the 3 variables.

\section{Treatment Effectiveness/Patient Satisfaction}

At each postoperative interval, patients were asked to evaluate the effectiveness of their treatment based on their pain, and in both groups, the percentage of patients choosing "completely recovered" or "much improved" remained consistently high out to 84 months after surgery: $86.1 \%$ of investigational and $77.4 \%$ of control patients. Seven years after their treatment, approximately $91 \%$ of CDA patients and $86 \%$ of ACDF patients were satisfied with the results of their surgery and would have the surgery again (Table 5).

\section{Radiographic Assessment}

Measurements of the FSU were made by the independent core lab over the course of the 7 years after each surgery in an effort to monitor disc height changes. A success or failure determination could not be made for approximately $40 \%$ of the investigational group at 84 months, due to both the gradual reduction in patient follow-up and to the visualization challenges inherent even in this measurement technique, which was a proxy for the more traditional endplate-to-endplate disc height measurement. In those patients for whom a measurement was obtained, FSU Success was above $90 \%$ for both treatment groups at all follow-up intervals, with the exception of the investigational group at 84 months with an $83.6 \%$ success rate; statistical noninferiority could not be concluded at 84 months.

The core lab also measured angular and translational motion at the index and adjacent levels at each postoperative follow-up visit. In the investigational group, mean angular motion was maintained through 84 months $\left(6.78^{\circ}\right)$, and mean translational motion was consistent throughout the postoperative course at the index level.

Adjacent level motion was also measured preoperatively and at each follow up. In the investigational group, mean angulation at the superior/inferior levels was $8.51^{\circ} / 6.09^{\circ}$ preoperatively and $9.31^{\circ} / 6.17^{\circ}$ at 84 months. In the control fusion group, superior/inferior adjacent level motion was $10.77^{\circ} / 7.77^{\circ}$ preoperatively and $10.71^{\circ} / 8.46^{\circ}$ at 84 months. Mean changes in adjacent level angular motion for each follow-up interval are presented in Table 6.

Heterotopic ossification was not included in the protocol-defined reporting responsibilities of the independent radiology reviewers. However, bridging bone, defined as evidence of a continuous connection of trabecular bone between vertebral bodies, was reported by the radiology core lab in $13.0 \%$ of investigational patients at 84 months. The relatively consistent mean angulation measurements at the index and adjacent levels, and the highly significant mean improvement in pain and disability scores up to 84 months after surgery, indicate little impact clinically from the bridging bone measures. 
Adverse Events

A time course summary of operative and postoperative adverse events is presented in Table 7, reporting the total number of AEs in each category and the number of patients involved. Statistical comparisons of the $\mathrm{AE}$ occurrence rates were made using predefined Bayesian methods (Table 8). Up to 84 months, the investigational group had a statistically higher rate of overall AEs, with a higher rate for the categories of anatomical or technical difficulty, implant event, urogenital AE, and vascular AE. As expected, the rate of nonunion events was significantly higher in the control group. To account for patients lost to follow up over the 7-year period, we conducted timeto-event analyses (Figure 4). The conclusion remains similar, except that the category of anatomical or technical difficulty is no longer statistically different between the 2 groups.

Table 5. Patient satisfaction at 84 months.

\begin{tabular}{|c|c|c|c|c|}
\hline Questionnaire & \multicolumn{2}{|c|}{$\begin{array}{r}\text { Investigational } \\
\% \text { (n) }\end{array}$} & & $\begin{array}{r}\text { Control } \\
\%(n)\end{array}$ \\
\hline \multicolumn{5}{|c|}{ I am satisfied with the results of my surgery } \\
\hline Definitely true & $79.3 \%$ & $(165)$ & $60.8 \%$ & $(110)$ \\
\hline Mostly true & $11.5 \%$ & (24) & $24.9 \%$ & $(45)$ \\
\hline Do not know & $6.3 \%$ & (13) & $6.1 \%$ & (11) \\
\hline Mostly false & $1.0 \%$ & (2) & $5.0 \%$ & (9) \\
\hline Definitely false & $1.9 \%$ & (4) & $3.3 \%$ & (6) \\
\hline \multicolumn{5}{|c|}{ I was helped as much as I thought I would be } \\
\hline Definitely true & $74.5 \%$ & $(155)$ & $59.9 \%$ & $(106)$ \\
\hline Mostly true & $14.9 \%$ & $(31)$ & $23.7 \%$ & $(42)$ \\
\hline Do not know & $4.8 \%$ & $(10)$ & $6.8 \%$ & $(12)$ \\
\hline Mostly false & $3.8 \%$ & (8) & $4.0 \%$ & (7) \\
\hline Definitely false & $1.9 \%$ & (4) & $5.6 \%$ & $(10)$ \\
\hline \multicolumn{5}{|c|}{ All things considered I would have the surgery again } \\
\hline Definitely true & $80.1 \%$ & $(172)$ & $72.3 \%$ & (128) \\
\hline Mostly true & $7.7 \%$ & (16) & $12.4 \%$ & $(22)$ \\
\hline Do not know & $5.8 \%$ & (12) & $10.7 \%$ & (19) \\
\hline Mostly false & $1.4 \%$ & (3) & $2.3 \%$ & (4) \\
\hline Definitely false & $1.9 \%$ & (4) & $2.3 \%$ & (4) \\
\hline
\end{tabular}


Table 6. Postoperative mean angular motion at adjacent levels.

\begin{tabular}{|c|c|c|c|c|c|c|}
\hline & \multicolumn{3}{|c|}{$\begin{array}{r}\text { Investigational } \\
(\mathbf{N}=\mathbf{2 8 0})\end{array}$} & \multicolumn{3}{|r|}{$\begin{array}{l}\text { Control } \\
(\mathrm{N}=265)\end{array}$} \\
\hline & $\mathrm{N}$ & Mean \pm SD & $P$ value & $\mathrm{N}$ & Mean \pm SD & $P$ value \\
\hline \multicolumn{7}{|l|}{1.5 months } \\
\hline Change in angulation at the segment above $\left(^{\circ}\right)$ & 266 & $-0.77 \pm 3.61$ & $<0.001$ & 187 & $-1.13 \pm 4.39$ & $<0.001$ \\
\hline Change in angulation at the segment below $\left({ }^{\circ}\right)$ & 172 & $-0.25 \pm 3.17$ & 0.298 & 86 & $0.70 \pm 3.67$ & 0.081 \\
\hline \multicolumn{7}{|l|}{3 months } \\
\hline Change in angulation at the segment above $\left(^{\circ}\right)$ & 264 & $0.32 \pm 3.85$ & 0.175 & 194 & $0.06 \pm 4.27$ & 0.841 \\
\hline Change in angulation at the segment below $\left(^{\circ}\right)$ & 174 & $0.29 \pm 3.48$ & 0.266 & 91 & $1.21 \pm 3.71$ & 0.002 \\
\hline \multicolumn{7}{|l|}{6 months } \\
\hline Change in angulation at the segment above $\left(^{\circ}\right)$ & 263 & $0.82 \pm 3.84$ & $<0.001$ & 198 & $0.53 \pm 4.26$ & 0.084 \\
\hline Change in angulation at the segment below $\left({ }^{\circ}\right)$ & 166 & $0.65 \pm 3.69$ & 0.025 & 94 & $0.99 \pm 3.93$ & 0.017 \\
\hline \multicolumn{7}{|l|}{12 months } \\
\hline Change in angulation at the segment above $\left(^{\circ}\right)$ & 267 & $1.27 \pm 3.75$ & $<0.001$ & 188 & $1.32 \pm 4.41$ & $<0.001$ \\
\hline Change in angulation at the segment below $\left(^{\circ}\right)$ & 166 & $1.11 \pm 3.47$ & $<0.001$ & 95 & $1.89 \pm 4.50$ & $<0.001$ \\
\hline \multicolumn{7}{|l|}{24 months } \\
\hline Change in angulation at the segment above $\left(^{\circ}\right)$ & 262 & $1.88 \pm 3.84$ & $<0.001$ & 187 & $1.04 \pm 4.60$ & 0.002 \\
\hline Change in angulation at the segment below $\left({ }^{\circ}\right)$ & 161 & $1.13 \pm 3.75$ & $<0.001$ & 94 & $1.28 \pm 4.28$ & 0.005 \\
\hline \multicolumn{7}{|l|}{36 months } \\
\hline Change in angulation at the segment above $\left({ }^{\circ}\right)$ & 225 & $1.53 \pm 3.92$ & $<0.001$ & 139 & $0.20 \pm 5.30$ & 0.639 \\
\hline Change in angulation at the segment below $\left({ }^{\circ}\right)$ & 143 & $1.69 \pm 3.83$ & $<0.001$ & 67 & $0.74 \pm 4.52$ & 0.187 \\
\hline \multicolumn{7}{|l|}{60 months } \\
\hline Change in angulation at the segment above $\left(^{\circ}\right)$ & 188 & $1.37 \pm 3.99$ & $<0.001$ & 159 & $-0.17 \pm 4.79$ & 0.663 \\
\hline Change in angulation at the segment below $\left({ }^{\circ}\right)$ & 117 & $1.11 \pm 4.37$ & 0.007 & 75 & $0.85 \pm 4.95$ & 0.143 \\
\hline \multicolumn{7}{|l|}{84 months } \\
\hline Change in angulation at the segment above $\left(^{\circ}\right)$ & 194 & $1.06 \pm 4.39$ & $<0.001$ & 152 & $-0.23 \pm 5.37$ & 0.604 \\
\hline Change in angulation at the segment below $\left(^{\circ}\right)$ & 127 & $1.25 \pm 4.06$ & $<0.001$ & 70 & $1.25 \pm 5.07$ & 0.043 \\
\hline
\end{tabular}

Downloaded from http://ijssurgery.com/ by guest on April 25, 2023 
Table 7. Time course summary of adverse events

\begin{tabular}{|c|c|c|c|c|c|c|c|c|c|c|c|c|c|c|c|c|c|c|c|c|c|c|c|c|c|c|}
\hline Interval* & 1 & 1 & 2 & 2 & 3 & 3 & 4 & 4 & 5 & 5 & 6 & 6 & 7 & 7 & 8 & 8 & 9 & 9 & 10 & 10 & 11 & 11 & 12 & 12 & Total & Total \\
\hline & $\mathrm{E}_{\dagger}^{\dagger}$ & $\mathrm{P} *$ & E & $\mathrm{P}$ & $\mathrm{E}$ & $\mathrm{P}$ & $\mathrm{E}$ & $\mathrm{P}$ & E & $P$ & $\mathrm{E}$ & $\mathrm{P}$ & $\mathrm{E}$ & $\mathrm{P}$ & E & $\mathrm{P}$ & $\mathrm{E}$ & $\mathrm{P}$ & $\mathrm{E}$ & $\mathrm{P}$ & $\mathrm{E}$ & $\mathrm{P}$ & $\mathrm{E}$ & $\mathrm{P}$ & E & P (\%) \\
\hline \multicolumn{27}{|l|}{ Investigational( $\mathrm{N}=280$ ) } \\
\hline Any adverse event & 29 & 25 & 173 & 80 & 179 & 89 & 241 & 117 & 246 & 115 & 401 & 146 & 312 & 116 & 328 & 97 & 218 & 79 & 300 & 89 & 222 & 71 & 125 & 62 & 2774 & $271(96.8)$ \\
\hline Anatomical/technical difficulty & 2 & 2 & 0 & 0 & 0 & 0 & 0 & 0 & 0 & 0 & 0 & 0 & 0 & 0 & 0 & 0 & 0 & 0 & 1 & 1 & 0 & 0 & 0 & 0 & 3 & $3(1.1)$ \\
\hline Cancer & 0 & 0 & 1 & 1 & 0 & 0 & 0 & 0 & 1 & 1 & 3 & 2 & 0 & 0 & 4 & 2 & 0 & 0 & 2 & 2 & 0 & 0 & 1 & 1 & 12 & $6(2.1)$ \\
\hline Cardiac disorders & 0 & 0 & 2 & 1 & 2 & 1 & 0 & 0 & 2 & 2 & 5 & 4 & 11 & 8 & 6 & 4 & 8 & 7 & 11 & 6 & 8 & 7 & 6 & 6 & 61 & $39(13.9)$ \\
\hline Death & 0 & 0 & 0 & 0 & 0 & 0 & 0 & 0 & 0 & 0 & 0 & 0 & 0 & 0 & 0 & 0 & 0 & 0 & 2 & 2 & 0 & 0 & 0 & 0 & 2 & $2(0.7)$ \\
\hline Dysphagia/dysphonia & 1 & 1 & 15 & 12 & 4 & 4 & 5 & 5 & 4 & 3 & 0 & 0 & 2 & 2 & 5 & 5 & 1 & 1 & 0 & 0 & 0 & 0 & 0 & 0 & 37 & $31(11.1)$ \\
\hline Gastrointestinal & 2 & 1 & 8 & 6 & 1 & 1 & 3 & 3 & 3 & 3 & 20 & 13 & 18 & 9 & 19 & 9 & 19 & 11 & 23 & 14 & 20 & 13 & 4 & 3 & 140 & $64(22.9)$ \\
\hline Heterotopic ossification & 0 & 0 & 2 & 2 & 6 & 5 & 2 & 2 & 4 & 3 & 3 & 3 & 6 & 6 & 5 & 5 & 5 & 5 & 6 & 6 & 5 & 4 & 8 & 7 & 52 & $44(15.7)$ \\
\hline Implant events & 6 & 6 & 1 & 1 & 2 & 2 & 2 & 2 & 0 & 0 & 0 & 0 & 4 & 4 & 1 & 1 & 1 & 1 & 4 & 4 & 0 & 0 & 1 & 1 & 22 & $20(7.1)$ \\
\hline Infection & 1 & 1 & 5 & 4 & 5 & 5 & 6 & 5 & 10 & 9 & 14 & 11 & 11 & 10 & 18 & 16 & 6 & 5 & 23 & 12 & 9 & 8 & 9 & 7 & 117 & $61(21.8)$ \\
\hline Neck and/or arm pain & 3 & 2 & 35 & 23 & 54 & 41 & 70 & 49 & 52 & 37 & 76 & 54 & 49 & 29 & 39 & 26 & 25 & 20 & 37 & 25 & 29 & 19 & 14 & 10 & 483 & $186(66.4)$ \\
\hline Neurological & 2 & 2 & 14 & 11 & 23 & 16 & 36 & 30 & 24 & 20 & 69 & 48 & 31 & 20 & 25 & 18 & 15 & 12 & 20 & 13 & 23 & 13 & 8 & 7 & 290 & $147(52.5)$ \\
\hline Non-union & 0 & 0 & 0 & 0 & 0 & 0 & 0 & 0 & 1 & 1 & 0 & 0 & 0 & 0 & 0 & 0 & 1 & 1 & 1 & 1 & 0 & 0 & 0 & 0 & 3 & $2(0.7)$ \\
\hline Other & 4 & 4 & 19 & 15 & 14 & 12 & 23 & 14 & 29 & 22 & 56 & 40 & 29 & 22 & 40 & 22 & 38 & 25 & 45 & 32 & 45 & 27 & 25 & 17 & 367 & $142(50.7)$ \\
\hline Other pain & 4 & 4 & 19 & 19 & 33 & 28 & 48 & 38 & 53 & 40 & 69 & 48 & 48 & 32 & 64 & 46 & 50 & 33 & 52 & 36 & 25 & 19 & 21 & 17 & 486 & $181(64.6)$ \\
\hline Respiratory & 0 & 0 & 8 & 6 & 0 & 0 & 1 & 1 & 11 & 8 & 1 & 1 & 13 & 11 & 3 & 3 & 1 & 1 & 13 & 10 & 12 & 7 & 5 & 4 & 68 & $46(16.4)$ \\
\hline Spinal event & 0 & 0 & 22 & 13 & 25 & 14 & 26 & 16 & 26 & 20 & 52 & 30 & 44 & 18 & 68 & 27 & 16 & 10 & 25 & 15 & 24 & 10 & 13 & 9 & 341 & $127(45.4)$ \\
\hline Trauma & 0 & 0 & 6 & 6 & 5 & 5 & 13 & 12 & 12 & 12 & 20 & 19 & 20 & 18 & 18 & 17 & 14 & 11 & 15 & 13 & 11 & 9 & 9 & 9 & 143 & $106(37.9)$ \\
\hline Urogenital & 1 & 1 & 1 & 1 & 2 & 2 & 1 & 1 & 8 & 6 & 11 & 8 & 16 & 12 & 7 & 6 & 14 & 8 & 14 & 11 & 7 & 6 & 1 & 1 & 83 & $51(18.2)$ \\
\hline Vascular & 3 & 3 & 1 & 1 & 1 & 1 & 1 & 1 & 2 & 2 & 0 & 0 & 5 & 4 & 4 & 3 & 4 & 4 & 5 & 3 & 4 & 3 & 0 & 0 & 30 & $24(8.6)$ \\
\hline Wound (non-infectious) & 0 & 0 & 14 & 10 & 2 & 2 & 4 & 3 & 4 & 1 & 2 & 2 & 5 & 4 & 2 & 2 & 0 & 0 & 1 & 1 & 0 & 0 & 0 & 0 & 34 & $23(8.2)$ \\
\hline Control (N=265) & & & & & & & & & & & & & & & & & & & & & & & & & & \\
\hline
\end{tabular}




\begin{tabular}{|c|c|c|c|c|c|c|c|c|c|c|c|c|c|c|c|c|c|c|c|c|c|c|c|c|c|c|}
\hline Any adverse event & 34 & 19 & 119 & 66 & 97 & 47 & 211 & 94 & 143 & 79 & 280 & 104 & 341 & 117 & 235 & 82 & 256 & 82 & 251 & 88 & 153 & 53 & 116 & 51 & 2236 & $232(87.5)$ \\
\hline Anatomical/technical difficulty & 0 & 0 & 0 & 0 & 0 & 0 & 0 & 0 & 0 & 0 & 0 & 0 & 0 & 0 & 0 & 0 & 0 & 0 & 0 & 0 & 0 & 0 & 0 & 0 & 0 & $0(0.0)$ \\
\hline Cancer & 0 & 0 & 1 & 1 & 0 & 0 & 0 & 0 & 0 & 0 & 0 & 0 & 1 & 1 & 1 & 1 & 0 & 0 & 1 & 1 & 1 & 1 & 0 & 0 & 5 & $5(1.9)$ \\
\hline Cardiac disorders & 0 & 0 & 2 & 2 & 1 & 1 & 2 & 2 & 3 & 2 & 3 & 3 & 9 & 9 & 7 & 4 & 5 & 4 & 5 & 5 & 6 & 6 & 3 & 3 & 46 & $37(14.0)$ \\
\hline Death & 0 & 0 & 0 & 0 & 0 & 0 & 1 & 1 & 0 & 0 & 1 & 1 & 1 & 1 & 0 & 0 & 2 & 2 & 0 & 0 & 0 & 0 & 0 & 0 & 5 & $5(1.9)$ \\
\hline Dysphagia/dysphonia & 5 & 4 & 11 & 11 & 4 & 4 & 3 & 3 & 0 & 0 & 1 & 1 & 0 & 0 & 0 & 0 & 3 & 2 & 4 & 4 & 0 & 0 & 0 & 0 & 31 & $26(9.8)$ \\
\hline Gastrointestinal & 7 & 4 & 7 & 5 & 3 & 2 & 4 & 4 & 3 & 3 & 21 & 12 & 24 & 13 & 8 & 7 & 16 & 11 & 12 & 8 & 9 & 5 & 6 & 5 & 120 & $64(24.2)$ \\
\hline Heterotopic ossification & 0 & 0 & 1 & 1 & 4 & 1 & 2 & 2 & 1 & 1 & 3 & 3 & 11 & 9 & 3 & 3 & 8 & 8 & 5 & 4 & 3 & 3 & 3 & 3 & 44 & $34(12.8)$ \\
\hline Implant events & 0 & 0 & 1 & 1 & 1 & 1 & 0 & 0 & 0 & 0 & 2 & 2 & 1 & 1 & 1 & 1 & 0 & 0 & 4 & 3 & 1 & 1 & 0 & 0 & 11 & $9(3.4)$ \\
\hline Infection & 2 & 1 & 3 & 3 & 5 & 5 & 2 & 2 & 1 & 1 & 10 & 9 & 14 & 10 & 10 & 9 & 6 & 6 & 4 & 4 & 10 & 9 & 11 & 8 & 78 & $49(18.5)$ \\
\hline Neck and/or arm pain & 2 & 1 & 18 & 14 & 19 & 15 & 49 & 37 & 42 & 33 & 55 & 44 & 41 & 28 & 28 & 19 & 36 & 24 & 23 & 19 & 5 & 3 & 24 & 18 & 342 & $156(58.9)$ \\
\hline Neurological & 6 & 5 & 24 & 20 & 18 & 11 & 36 & 24 & 17 & 13 & 57 & 34 & 61 & 35 & 42 & 29 & 28 & 19 & 30 & 24 & 11 & 11 & 18 & 12 & 348 & $144(54.3)$ \\
\hline Non-union & 0 & 0 & 0 & 0 & 3 & 3 & 4 & 4 & 9 & 9 & 9 & 9 & 9 & 9 & 1 & 1 & 0 & 0 & 2 & 2 & 0 & 0 & 1 & 1 & 38 & $35(13.2)$ \\
\hline Other & 3 & 2 & 14 & 12 & 13 & 10 & 17 & 13 & 10 & 10 & 20 & 14 & 54 & 31 & 26 & 19 & 31 & 24 & 43 & 27 & 31 & 19 & 13 & 12 & 275 & $123(46.4)$ \\
\hline Other pain & 6 & 4 & 19 & 16 & 10 & 10 & 44 & 33 & 28 & 25 & 58 & 40 & 60 & 43 & 49 & 34 & 45 & 33 & 50 & 33 & 30 & 24 & 19 & 15 & 418 & $167(63.0)$ \\
\hline Respiratory & 0 & 0 & 4 & 3 & 4 & 2 & 1 & 1 & 5 & 4 & 1 & 1 & 8 & 7 & 4 & 4 & 2 & 2 & 10 & 8 & 8 & 5 & 3 & 2 & 50 & $32(12.1)$ \\
\hline Spinal event & 0 & 0 & 8 & 6 & 6 & 5 & 30 & 15 & 15 & 9 & 22 & 12 & 33 & 17 & 31 & 16 & 47 & 25 & 30 & 18 & 14 & 8 & 6 & 5 & 242 & $106(40.0)$ \\
\hline Trauma & 0 & 0 & 2 & 2 & 4 & 4 & 12 & 11 & 5 & 5 & 9 & 8 & 12 & 10 & 15 & 14 & 20 & 20 & 15 & 14 & 15 & 13 & 7 & 7 & 116 & $79(29.8)$ \\
\hline Urogenital & 0 & 0 & 0 & 0 & 0 & 0 & 1 & 1 & 3 & 3 & 5 & 4 & 2 & 2 & 6 & 4 & 5 & 3 & 11 & 7 & 7 & 5 & 1 & 1 & 41 & $26(9.8)$ \\
\hline Vascular & 1 & 1 & 0 & 0 & 0 & 0 & 1 & 1 & 0 & 0 & 1 & 1 & 0 & 0 & 1 & 1 & 2 & 2 & 1 & 1 & 1 & 1 & 0 & 0 & 8 & $8(3.0)$ \\
\hline Wound (non-infectious) & 2 & 2 & 4 & 4 & 2 & 2 & 2 & 2 & 1 & 1 & 2 & 2 & 0 & 0 & 2 & 2 & 0 & 0 & 1 & 1 & 1 & 1 & 1 & 1 & 18 & $18(6.8)$ \\
\hline
\end{tabular}

*Intervals: (1) Operative; (2) 1 day; (3) 1.5 months; (4) 3 months; (5) 6 months; (6) 12 months; (7) 24 months; (8) 36 months; (9) 48 months; (10) 60 months; (11) 72 months; (12) 84 months. †E = Number of events; $\neq$ P = Number of patients. 
Any adverse event that required a second surgery at the index level was classified according to the protocol in 1 of 4 ways: revisions, removals, supplemental fixations, or reoperations. A revision was defined as a procedure that adjusted or in any way modified the original implant configuration. A removal was defined as a procedure that removed 1 or more components of the original implant configuration without replacement with the same type of device. Supplemental fixation was defined as a procedure in which additional spinal devices not approved as part of the protocol were placed and included supplemental treatments, such as bone growth stimulators. A reoperation was defined as any surgical procedure at the treated spinal level that did not remove, modify, or add any components. Secondary surgical interventions occurred in both treatment groups, and results at 84 months are compared in Table 9. The mean difference in the rate of supplemental fixation procedures between the investigational and the control group was -0.030 ( $95 \%$ credible interval was -0.058 to -0.009). The posterior probability that the investigational group had a lower rate of supplemental fixation procedures was 0.998 , demonstrating statistical superiority of the investigational group over the control group. Excluding external bone growth stimulators from supplemental fixation, rates were similar between the 2 groups. To account for patients lost to follow-up, time-to-event analyses were also conducted, with no resulting change in conclusions (Figure

Table 8. Comparisons of adverse events at 84-month interval.

\begin{tabular}{|c|c|c|c|c|c|c|c|}
\hline \multirow[t]{2}{*}{ Variable } & \multicolumn{2}{|c|}{$p_{1}$ (Investigational) } & \multicolumn{2}{|r|}{$p_{0}$ (Control) } & \multicolumn{2}{|r|}{$\mathbf{p}_{1}-\mathbf{p}_{0}$} & \multirow[t]{2}{*}{ Probability of Superiority } \\
\hline & Mean & $95 \% \mathrm{HPD}$ & Mean & 95\% HPD & Mean & $95 \%$ HPD & \\
\hline Anatomical/technical difficulty & 0.006 & $(0.0003,0.019)$ & 0.000 & $(0.000,0.000)$ & 0.006 & $(0.0003,0.019)$ & 0.003 \\
\hline Cancer & 0.023 & $(0.008,0.044)$ & 0.014 & $(0.004,0.032)$ & 0.009 & $(-0.015,0.033)$ & 0.224 \\
\hline Cardiac disorders & 0.127 & $(0.090,0.170)$ & 0.148 & $(0.106,0.196)$ & -0.021 & $(-0.084,0.041)$ & 0.749 \\
\hline Dysphagia/dysphonia & 0.109 & $(0.075,0.150)$ & 0.098 & $(0.064,0.139)$ & 0.011 & $(-0.046,0.066)$ & 0.351 \\
\hline Gastrointestinal & 0.228 & $(0.179,0.281)$ & 0.241 & $(0.189,0.298)$ & -0.013 & $(-0.092,0.064)$ & 0.632 \\
\hline Heterotopic ossification & 0.163 & $(0.121,0.210)$ & 0.122 & $(0.084,0.166)$ & 0.041 & $(-0.022,0.105)$ & 0.104 \\
\hline Implant events & 0.074 & $(0.045,0.110)$ & 0.031 & $(0.014,0.055)$ & 0.044 & $(0.005,0.085)$ & 0.014 \\
\hline Infection & 0.219 & $(0.171,0.272)$ & 0.183 & $(0.137,0.234)$ & 0.037 & $(-0.037,0.109)$ & 0.163 \\
\hline Neck and/or arm pain & 0.658 & $(0.598,0.715)$ & 0.597 & $(0.536,0.657)$ & 0.061 & $(-0.027,0.148)$ & 0.086 \\
\hline Neurological & 0.527 & $(0.466,0.587)$ & 0.542 & $(0.478,0.605)$ & -0.015 & $(-0.108,0.077)$ & 0.624 \\
\hline Non-union & 0.007 & $(0.001,0.020)$ & 0.133 & $(0.092,0.181)$ & -0.126 & $(-0.174,-0.083)$ & $\sim 1.000$ \\
\hline Other & 0.498 & $(0.436,0.560)$ & 0.474 & $(0.412,0.537)$ & 0.025 & $(-0.067,0.117)$ & 0.300 \\
\hline Other pain & 0.636 & $(0.575,0.693)$ & 0.643 & $(0.581,0.702)$ & -0.007 & $(-0.096,0.083)$ & 0.552 \\
\hline Respiratory & 0.155 & $(0.113,0.202)$ & 0.125 & $(0.088,0.169)$ & 0.030 & $(-0.034,0.093)$ & 0.176 \\
\hline Spinal event & 0.463 & $(0.404,0.525)$ & 0.389 & $(0.327,0.451)$ & 0.074 & $(-0.015,0.167)$ & 0.053 \\
\hline Trauma & 0.370 & $(0.313,0.430)$ & 0.305 & $(0.249,0.364)$ & 0.065 & $(-0.020,0.151)$ & 0.067 \\
\hline Urogenital & 0.173 & $(0.129,0.223)$ & 0.102 & $(0.067,0.143)$ & 0.071 & $(0.007,0.134)$ & 0.016 \\
\hline Vascular & 0.084 & $(0.053,0.121)$ & 0.030 & $(0.013,0.056)$ & 0.054 & $(0.014,0.096)$ & 0.005 \\
\hline Wound (non-infection) & 0.089 & $(0.057,0.127)$ & 0.056 & $(0.032,0.088)$ & 0.032 & $(-0.013,0.079)$ & 0.086 \\
\hline Any adverse event & 0.968 & $(0.943,0.985)$ & 0.877 & $(0.832,0.917)$ & 0.090 & $(0.044,0.141)$ & 0.000 \\
\hline
\end{tabular}


5).

The percentage of patients undergoing secondary surgeries at the adjacent level alone or in conjunction with the index level, cumulatively up to the 84-month follow up, was similar: $9.6 \%$ of investigational and $8.3 \%$ of control patients.

Device- and device/surgical procedure-related AEs were reported in $17.5 \%$ of investigational and $16.6 \%$ of control patients. The incidence of AEs that were both serious and classified as device- and device/surgical procedure-related events was also similar in the investigational (6.1\%) and control (5.6\%) groups.

\section{Discussion}

In this study, we report a continuation of the successful results seen at 24 months for patients treated with the Prestige LP Cervical Disc device at 7 years after
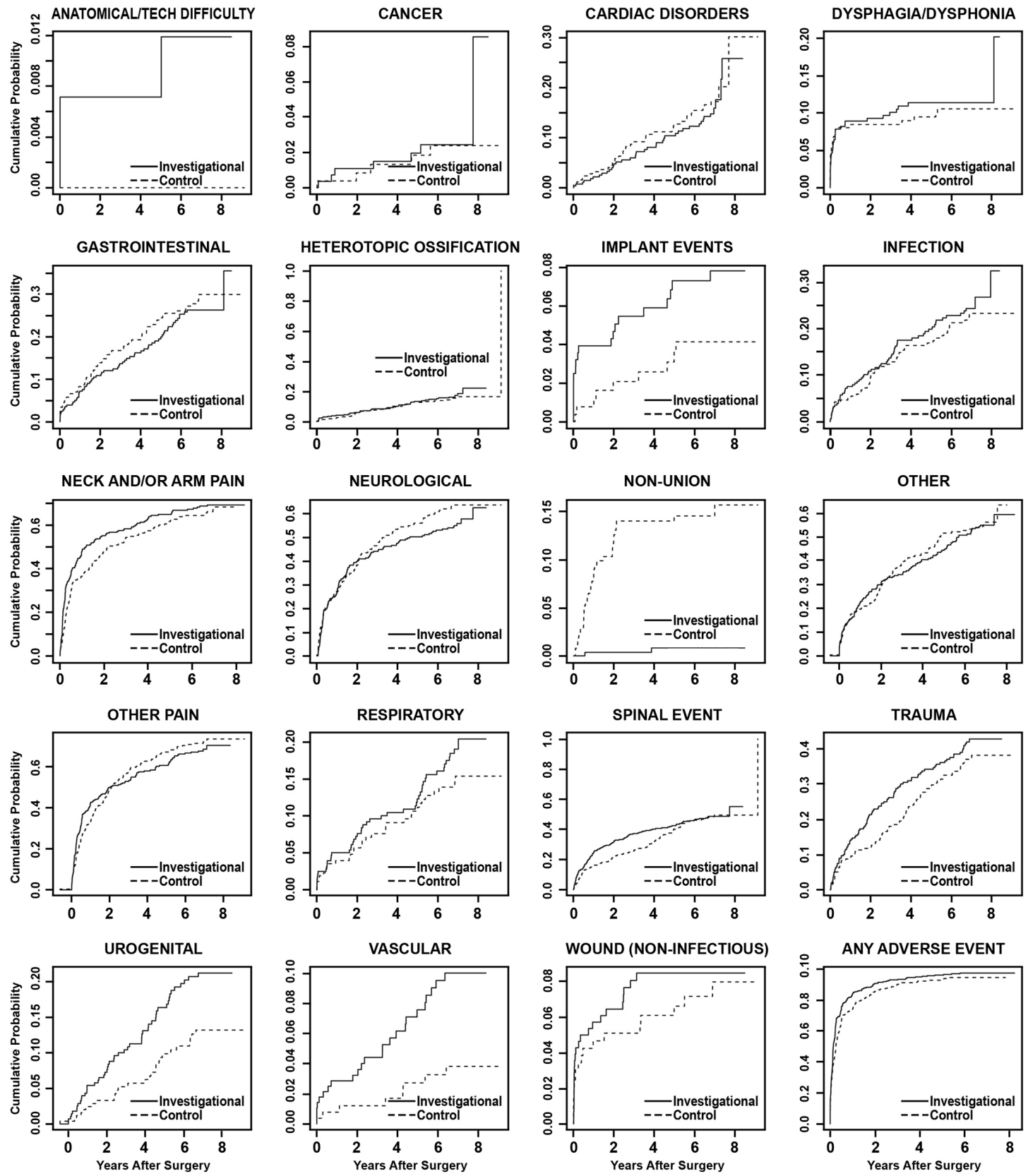

Fig. 4. Time-to-event analyses (Kaplan-Meier curves) showing cumulative probabilities by adverse event category for the investigational and control groups. $\mathrm{P}$ values are based on Cox proportional hazards models, adjusted for propensity score. 
surgery. Statistical superiority or noninferiority was concluded for CDA compared with ACDF with respect to key clinical and radiographic outcomes, as improvements versus baseline in mean pain and disability measures were statistically significant in both groups at each follow-up interval after surgery. Safety measures including device- and device/surgical procedure-related adverse events and second surgeries were also statistically similar in the investiga- tional and control groups out to seven years. Patient satisfaction was likewise high in both groups.

Articulating prosthetic implants are subject to wear and corrosion following implantation. An advantage of metal-on-metal bearings is the substantially lower volumetric wear debris when compared with conventional metal-on-polyethylene bearing couples. However, implant wear can lead to local and systemic

Table 9. Comparisons of secondary surgical events at 84 months.

\begin{tabular}{|c|c|c|c|c|c|c|c|c|c|}
\hline \multirow[t]{2}{*}{ Surgical Event } & \multicolumn{3}{|c|}{$\mathbf{p}_{1}$ (Investigational) } & \multicolumn{3}{|r|}{$\mathrm{p}_{0}($ Control $)$} & \multicolumn{2}{|r|}{$\mathbf{p}_{1}-\mathbf{p}_{0}$} & \multirow[t]{2}{*}{ Probability of Superiority } \\
\hline & $\mathrm{N}$ & Mean & $95 \% \mathrm{HPD}$ & $\mathrm{N}$ & Mean & $95 \% \mathrm{HPD}$ & Mean & $95 \% \mathrm{HPD}$ & \\
\hline Revisions & 1 & 0.004 & $(0.000,0.014)$ & 5 & 0.016 & $(0.004,0.036)$ & -0.012 & $(-0.033,0.003)$ & 0.938 \\
\hline Removal & 14 & 0.049 & $(0.026,0.079)$ & 8 & 0.030 & $(0.013,0.054)$ & 0.019 & $(-0.015,0.055)$ & 0.139 \\
\hline Supplemental Fixation & 2 & 0.005 & $(0.0005,0.015)$ & 9 & 0.036 & $(0.0160 .063)$ & -0.030 & $(-0.058-0.009)$ & 0.998 \\
\hline Supplemental Fixation w/o BGS & 2 & 0.005 & $(0.0005,0.015)$ & 5 & 0.019 & $(0.006,0.040)$ & -0.014 & $(-0.0350 .002)$ & 0.962 \\
\hline Reoperations & 3 & 0.011 & $(0.002,0.027)$ & 4 & 0.011 & $(0.002,0.027)$ & 0.001 & $(-0.018,0.018)$ & 0.463 \\
\hline Other & 130 & 0.460 & $(0.398,0.522)$ & 106 & 0.404 & $(0.344,0.466)$ & 0.056 & $(-0.037,0.145)$ & 0.119 \\
\hline
\end{tabular}

BGS = bone growth stimulator, HPD = highest posterior density
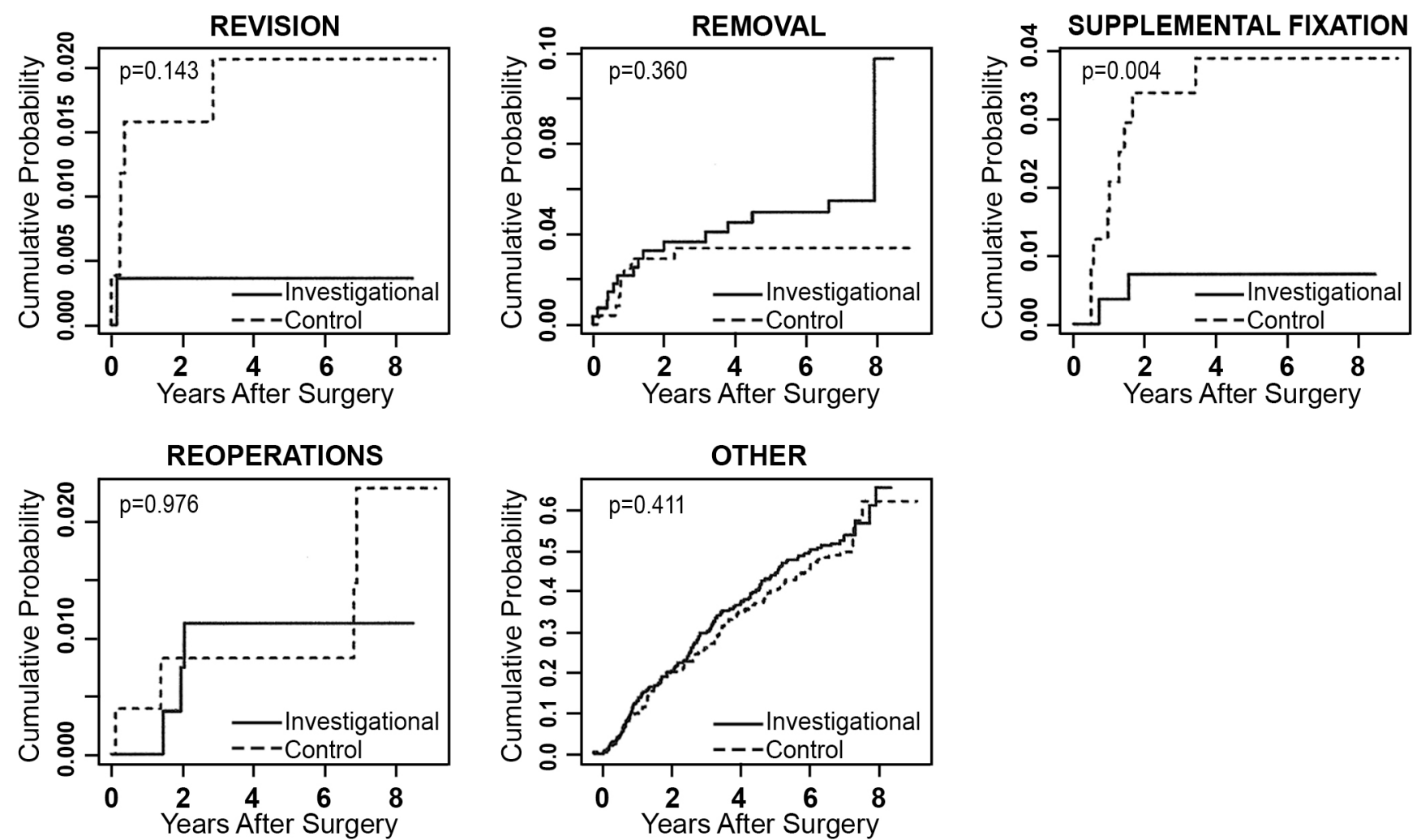

Fig. 5. Time-to-event analyses (Kaplan-Meier curves) showing cumulative probabilities of the classifications of secondary surgeries for the investigational and control groups. P values are based on Cox proportional hazards models, adjusted for propensity score. 
transport of metal debris and increased levels of serum ions. Patients with Prestige LP cervical disc replacements experience increased serum metal ion concentrations after surgery (Gornet MF, Singh V, Schranck FW, Skipor AK, Jacobs JJ: Serum metal ion levels after surgery in patients with metal-on-metal cervical disc arthroplasty. A prospective study up to 84 months. Paper presented at the 30th Annual Meeting of the North American Spine Society. Chicago, IL, October 14-17, 2015). Importantly, the toxicological sequelae of these chronic elevated local and systemic metal levels have not been determined. Several case studies have reported some early local effect of wear debris. ${ }^{25,26}$

Cervical disc arthroplasty has the potential for preserving motion at the operated level while providing biomechanical stability and global neck mobility. Restoration or maintenance of physiologic motion at the treated level may result in a reduction in adjacent segment degeneration (ASD) and the need for additional surgery. Although cervical disc replacement and anterior cervical fusion are both safe procedures with a low incidence of significant adverse events related to the procedure, more additional surgeries occurred in the investigational group (CDA) than in the control (ACDF) group. Cervical disc arthroplasty may provide the benefits of neural decompression without placing adjacent motion segments at risk for accelerated degeneration; however, there is no consensus that CDA provides a reduction in ASD rates in longer-term studies. ${ }^{13,19,27}$

The absence of randomization in this study may be considered a shortcoming. This historical control approach, however, was approved by the FDA based on the identical inclusion/exclusion criteria, as well as the Bayesian propensity score techniques which provided statistical balance to all covariates and validated the comparability of the groups.

With one exception, ${ }^{28}$ the rate of neurological success in the ACDF control group is lower than typically reported. ${ }^{1,10,11,29}$ We cannot definitively explain this lower rate nor the rate difference between CDA and $\mathrm{ACDF}$ in the current study. Caution is advised in making comparisons across studies because measurement and reporting of neurological success varies, therefore, statistical comparisons may not be valid. We can, however, speculate about several possible reasons for the lower success rate in this study: surgical technique, pseudarthrosis rates, ASD, and bias. First, the surgical technique of the CDA involved a more thorough dissection and decompression than that required in the ACDF control group. The CDA required an extensive posterior and posterolateral decompression across the disc space. The entire posterior annulus and posterior longitudinal ligament were resected and uncovertebral joints were partially removed. This decompression may have been less meticulously performed in the ACDF group. Second, relatively high subsidence/pseudarthrosis rates after ACDF have been widely published and may contribute over time to unfavorable changes in neurological status. Third, the increasing incidence of ASD observed after ACDF may be contributing to new neurological pathology--especially as the length of follow-up increases. Finally, we cannot rule out the possible influence of expectations from the treating surgeons. In the absence of blinding, surgeons' expectations about inferior performance compared with new motion preservation technology may have negatively impacted their assessment of ACDF patients.

Several encouraging clinical and radiographic findings have come from the long-term patient follow-up of this prospective study with concurrent enrollment out to seven years after surgery using the Prestige LP implant. Statistically significant improvements in validated clinical outcome measurements were maintained out to 7 years.

The Prestige LP Disc maintained physiologic segmental motion at 84 months after implantation with a mean flexion-extension difference of $6.78^{\circ}$. Mean translational motion was consistent throughout the postoperative course at the index level. In addition, there were no reported implant migrations. The rates of spontaneous fusion, as measured by the presence of bridging bone, and subsidence, as measured by FSU height, were very low.

Thousands of patients have now undergone cervical disc arthroplasty in very large prospective, multicenter IDE studies in the United States, and this collec- 
tive body of Level 1 evidence, much of it now with results up to 7 years after surgery, is consistent and convincing in its support of CDA as an alternative to ACDF in appropriately selected patients. In many of these published studies, the outcomes evidence includes a conclusion of statistical superiority for CDA compared with ACDF. Adding to that support is the growing body of longer term cost effectiveness da$\mathrm{ta}^{18,30-32}$ that concludes that CDA is economically superior to ACDF. Nevertheless, single-level CDA utilization rates in the United States have thus far trailed expectations due, in part, to limited coverage and reimbursement by insurers.

\section{Conclusions}

Patients treated with the Prestige LP Cervical Disc reported significantly improved pain and disability outcomes, at least equivalent to those of the historical control fusion group, 84 months after surgery. Key measures of safety were similar for investigational and control patients. At 84 months, patient satisfaction with the results of surgery was high in both groups. Additional surgical procedures for adjacent segment disease were observed in both treatment groups. Some of the second surgeries involved both index and adjacent levels. Rates for surgery at adjacent levels were similar between the groups and were not statistically significant.

\section{References}

1. Hisey MS, Bae HW, Davis R, Gaede S, Hoffman G, Kim K, et al: Multi-center, prospective, randomized, controlled investigational device exemption clinical trial comparing Mobi-C Cervical Artificial Disc to anterior discectomy and fusion in the treatment of symptomatic degenerative disc disease in the cervical spine. Int J Spine Surg. 2014 Dec 1;8. doi: 10.14444/1007.

2. Mummaneni PV, Burkus JK, Haid RW, Traynelis VC, Zdeblick TA: Clinical and radiographic analysis of cervical disc arthroplasty compared with allograft fusion: a randomized controlled clinical trial. J Neurosurg Spine. 2007 Mar;6(3):198-209.

PMID:17355018.

3. Murrey D, Janssen M, Delamarter R, Goldstein
J, Zigler J, Tay B, et al: Results of the prospective, randomized, controlled multicenter Food and Drug Administration investigational device exemption study of the ProDisc-C total disc replacement versus anterior discectomy and fusion for the treatment of 1-level symptomatic cervical disc disease. Spine J. 2009 Apr;9(4):275-86. doi: 10.1016/ j.spinee.2008.05.006. Epub 2008 Sep 6.PMID:18774751.

4. Phillips FM, Lee JYB, Geisler FH, Cappuccino A, Chaput CD, DeVine JG, et al: A prospective, randomized, controlled clinical investigation comparing PCM cervical disc arthroplasty with anterior cervical discectomy and fusion. 2-year results from the US FDA IDE clinical trial. Spine (Phila Pa 1976). 2013 Jul 1;38(15):E907-18. doi: 10.1097/

BRS.0b013e318296232f

5. Sasso RC, Smucker JD, Hacker RJ, Heller JG: Clinical outcomes of BRYAN cervical disc arthroplasty: a prospective, randomized, controlled, multicenter trial with 24-month follow-up. J Spinal Disord Tech. 2007 Oct;20(7):481-91. PMID:17912124.

6. Vaccaro A, Beutler W, Peppelman W, Marzluff JM, Highsmith J, Mugglin A, et al.: Clinical outcomes with selectively constrained SECURE-C cervical disc arthroplasty: two-year results from a prospective, randomized, controlled, multicenter investigational device exemption study. Spine (Phila $\mathrm{Pa}$ 1976). 2013 Dec 15;38(26):2227-39. doi: 10.1097/ BRS.0000000000000031.

7. Bae HW, Kim KD, Nunley PD, Jackson RJ, Hisey MS, Davis RJ, et al: Comparison of clinical outcomes of 1- and 2-level total disc replacement: 4-year results from a prospective, randomized, controlled, multicenter IDE clinical trial. Spine (Phila Pa 1976). 2015 Jun 1;40(11):759-66. doi: 10.1097/ BRS.0000000000000887.

8. Burkus JK, Traynelis VC, Haid RW, Mummaneni PV: Clinical and radiographic analysis of an artificial cervical disc: 7-year follow-up from the Prestige prospective randomized controlled clinical trial. J Neurosurg Spine. 2014 Oct;21(4):516-28. doi: 10.3171/2014.6.SPINE13996. Epub 2014 Jul 18. 9. Davis RJ, Nunley PD, Kim KD, Hisey MS, Jackson RJ, Bae HW, et al.: Two-level total disc replacement with Mobi-C cervical artificial disc versus anterior discectomy and fusion: a prospective, random- 
ized, controlled multicenter clinical trial with 4-year follow-up results. J Neurosurg Spine. 2015 Jan;22(1):15-25. doi: 10.3171/2014.7.

10. Phillips FM, Geisler FH, Gilder KM, Reah C, Howell KM, McAfee PC: Long-term outcomes of the US FDA IDE prospective, randomized controlled clinical trial comparing PCM cervical disc arthroplasty with anterior cervical discectomy and fusion. Spine (Phila Pa 1976). 2015 May

15;40(10):674-83. doi: 10.1097/

BRS.0000000000000869.

11. Zigler JE, Delamarter R, Murrey D, Spivak J, Janssen M: ProDisc-C and anterior cervical discectomy and fusion as surgical treatment for single-level cervical symptomatic degenerative disc disease: fiveyear results of a Food and Drug Administration study. Spine (Phila Pa 1976). 2013 Feb 1;38(3):203-9. doi: 10.1097/BRS.0b013e318278eb38.

12. Beutler WJ, Sweeney CA, Connolly PJ: Recurrent laryngeal nerve injury with anterior cervical spine surgery risk with laterality of surgical approach. Spine (Phila Pa 1976). 2001 Jun 15;26(12):1337-42. PMID:11426148 13. Blumenthal SL, Ohnmeiss DD, Guyer RD, Zigler JE: Reoperations in cervical total disc replacement compared with anterior cervical fusion: results compiled from multiple prospective food and drug administration investigational device exemption trials conducted at a single site. Spine (Phila Pa 1976). 2013 Jun 15;38(14):1177-82. doi: 10.1097/ BRS.0b013e31828ce774.

14. Bohlman HH, Emery SE, Goodfellow DB, Jones PK: Robinson anterior cervical discectomy and arthrodesis for cervical radiculopathy. Long-term follow-up of one hundred and twenty-two patients. J Bone Joint Surg Am. 1993 Sep;75(9):1298-307. PMID:8408151.

15. Harrod CC, Hilibrand AS, Fischer DJ, Skelly AC: Adjacent segment pathology following cervical motion-sparing procedures or devices compared with fusion surgery: a systematic review. Spine (Phila Pa 1976). 2012 Oct 15;37(22 Suppl):S96-S112. doi: 10.1097/BRS.0b013e31826cb2d6.

16. Hilibrand AS, Carlson GD, Palumbo MA, Jones PK, Bohlman HH: Radiculopathy and myelopathy at segments adjacent to the site of a previous anterior cervical arthrodesis. J Bone Joint Surg Am. 1999
Apr;81(4):519-28. PMID: 10225797.

17. Kim HJ, Kelly MP, Ely CG, Dettori JR, Riew

$\mathrm{KD}$ : The risk of adjacent-level ossification development after surgery in the cervical spine: are there factors that affect the risk? A systematic review. Spine (Phila Pa 1976). 2012 Oct 15;37(22 Suppl):S65-74. doi: 10.1097/BRS.0b013e31826cb8f5. 18. Radcliff K, Zigler J, Zigler J: Costs of cervical disc replacement versus anterior cervical discectomy and fusion for treatment of single-level cervical disc disease: an analysis of the Blue Health Intelligence database for acute and long-term costs and complications. Spine (Phila Pa 1976). $2015 \mathrm{Apr}$

15;40(8):521-9. doi: 10.1097/

BRS.0000000000000822.

19. Riew KD, Schenk-Kisser JM, Skelly AC: Adjacent segment disease and C-ADR: promises fulfilled? Evid Based Spine Care J. 2012 Feb;3(S1):39-46. doi: 10.1055/s-0031-1298607.

20. Yue W-M, Brodner W, Highland TR: Longterm results after anterior cervical discectomy and fusion with allograft and plating: a 5- to 11-year radiologic and clinical follow-up study. Spine (Phila $\mathrm{Pa}$ 1976). 2005 Oct 1;30(19):2138-44. PMID:16205338. 21. Zigler JE, Glenn J, Delamarter RB: Five-year adjacent-level degenerative changes in patients with single-level disease treated using lumbar total disc replacement with ProDisc-L versus circumferential fusion. J Neurosurg Spine. 2012 Dec;17(6):504-11. doi: 10.3171/2012.9.SPINE11717. Epub 2012 Oct 19.

22. Gornet MF, Burkus JK, Shaffrey ME, Argires PJ, Nian H, Harrell FE: Cervical disc arthroplasty with PRESTIGE LP disc versus anterior cervical discectomy and fusion: a prospective, multicenter investigational device exemption study. J Neurosurg Spine. 2015 Jul 31:1-16. [Epub ahead of print] PMID: 26230424.

23. McHorney CA, Ware JE Jr, Lu JF, Sherbourne CD: The MOS 36-item Short-Form Health Survey (SF-36): III. Tests of data quality, scaling assumptions, and reliability across diverse patient groups. Med Care 1994 Jan; 32:40-66. PMID: 8277801 24. McDowell I, Newell, Claire: Measuring Health: A Guide to Rating Scales and Questionnaires. 2nd ed, New York: Oxford University Press, 1996. 25. Cavanaugh DA, Nunley PD, Kerr EJ, Werner DJ, Jawahar A: Delayed hyper-reactivity to metal 
ions after cervical disc arthroplasty: a case report and literature review. Spine (Phila Pa 1976). 2009 Apr 1;34(7):E262-5. doi: 10.1097/

BRS.0b013e318195dd60.

26. Hacker FM, Babcock RM, Hacker RJ: Very late complications of cervical arthroplasty: results of 2 controlled randomized prospective studies from a single investigator site. Spine (Phila Pa 1976). 2013

Dec 15;38(26):2223-6. doi: 10.1097/

BRS.0000000000000060.

27. Verma K, Gandhi SD, Maltenfort M, Albert TJ, Hilibrand AS, Vaccaro AR, et al.: Rate of adjacent segment disease in cervical disc arthroplasty versus single-level fusion: meta-analysis of prospective studies. Spine (Phila Pa 1976). 2013 Dec

15;38(26):2253-7. doi: 10.1097/

BRS.0000000000000052.

28. Delamarter RB, Murrey D, Janssen ME, et al. Results at 24 months from the prospective, randomized, multicenter Investigational Device Exemption trial of ProDisc-C versus anterior cervical discectomy and fusion with 4-year follow-up and continued access patients. SAS J 2010;4:122-8

29. Heller JG, Sasso RC, Papadopoulos SM, et al. Comparison of BRYAN cervical disc arthroplasty with anterior cervical decompression and fusion: clinical and radiographic results of a randomized, controlled, clinical trial. Spine (Phila Pa 1976) 2009;34:101-7.

30. Alvin MD, Qureshi S, Klineberg E, Riew KD, Fischer DJ, Norvell DC, et al: Cervical degenerative disease: systematic review of economic analyses. Spine (Phila Pa 1976). 2014;39: Oct 15.S53-64. doi: 10.1097/BRS.0000000000000547.

31. McAnany SJ, Overley S, Baird EO, Cho SK, Hecht AC, Zigler JE, et al: The 5-year cost-

effectiveness of anterior cervical discectomy and fusion and cervical disc replacement: a Markov analysis. Spine (Phila Pa 1976). 2014 Nov

1;39(23):1924-33. doi: 10.1097/

BRS.0000000000000562.

32. Wiedenhöfer B, Nacke J, Stephan M, Richter
W, Carstens C, Eichler M: Is Total Disc Replacement a Cost Effective Treatment for Cervical Degenerative Disc Disease? J Spinal Disord Tech.2014 Oct 10. [Epub ahead of print]. PMID:25310395.

\section{Disclosures \& COI}

Dr. Burkus reports research support from Medtronic, during the conduct of the study; research support from Medtronic and Zimmer/Biomet outside the submitted work; In addition, Dr. Burkus has a patent with paid royalties from Zimmer/Biomet. Dr. Gornet reports stock ownership in Bonovo; stock in the International Spine and Orthopedic Institute; consultancy for K2M, research support, consultancy, and royalties from Medtronic; stock ownership in Nocimed; stock ownership in OuroBoros; stock ownership in Viscogliosi Brothers Venture Partners, outside the submitted work. Dr. Harrell has nothing to disclose. Dr. Nian reports contract funding for statistical analysis from Medtronic during the conduct of the study. Dr. Schaffrey has nothing to disclose.

This investigational device exemption study was sponsored by Medtronic Spinal and Biologics, Memphis, TN. Study approved by the Hughston Sports Medicine Center Institutional Review Board on January $7,2005$.

\section{Corresponding Author}

Matthew F. Gornet, MD, Spine Research Center, 14825 North Outer Forty Road, Suite 320, St. Louis, Missouri 63017. Phone: (314) 392-5089; Fax: (314) 336-2645; Email:mfgspine@gmail.com.

Published 22 June 2016.

This manuscript is generously published free of charge by ISASS, the International Society for the Advancement of Spine Surgery. Copyright @ 2016 ISASS. To see more or order reprints or permissions, see http://ijssurgery.com. 